DR. CREIGHTON CONNOLLY (Orcid ID : 0000-0002-4782-2621)

Article type : Regular Paper

\title{
Urban Political Ecologies of Heritage: Integrating Cultural and Nat- ural Landscapes in Penang, Malaysia
}

Article accepted for publication in Transactions of the Institute of British Geographers. The information, practices and views in this article are those of the author(s) and do not necessarily reflect the opinion of the Royal Geographical Society (with IBG).

\author{
Author: \\ Creighton Connolly \\ School of Geography, University of Lincoln, Lincoln, UK \\ Email: cconnolly@lincoln.ac.uk \\ ORCID iD: https://orcid.org/0000-0002-4782-2621
}

\begin{abstract}
Over the past few decades, there have been numerous studies examining the interface between cultural heritage conservation and urban (re)development, particularly in rapidly developing regions. On the other hand, scholars have also examined nature conservation movements in the context of encroaching (urban) development. However, this body of research has, with a few exceptions, not considered the inter-relationship between natural and cultural heritage in urban settings. The paper argues that a renewed understanding of urban heritage - consisting of both cultural and natural elements - is required for effective and socio-ecologically sustainable approaches to heritage conservation and urban development. To illustrate this argument, the paper draws on an empirical examination of Penang Hill, which is a culturally and ecologically significant area of Penang Island, Malaysia. In conceptualising this relationship, the paper draws on the urban political ecologies of landscape, which is useful in examining the urbanisation of nature and problematising distinctions between urban/rural and natural/cultural. As I will demonstrate, invocations of Penang's rich natural heritage are often framed alongside urban and cultural heritage in local resistance to these developments, which relate to the particular socio-environmental sensibilities of local stakeholders. The analysis is based on discursive analysis of primary written sources and original interviews with local residents and civil society activists, which helps to demonstrate the crucial role of local communities in achieving more socio-ecologically just forms of heritage management.
\end{abstract}

This article has been accepted for publication and undergone full peer review but has not been through the copyediting, typesetting, pagination and proofreading process, which may lead to differences between this version and the Version of Record. Please cite this article as doi: $10.1111 / \operatorname{tran} .12335$

This article is protected by copyright. All rights reserved. 
Acknowledgements: The research for this paper was made possible by a Research Grant from the Asia Research Institute, National University of Singapore, for the project 'Negotiating Urban Heritage: Contesting Visions of Redevelopment in Penang, Malaysia' (2016-2017). Thanks are also due to Grace Chong who provided assistance with the literature review, in addition to Maria Kaika and three anonymous reviewers who provided helpful comments on previous drafts.

Funding information: Asia Research Institute, National University of Singapore

Data accessibility statement: The data that support the findings of this study are available on request from the corresponding author. The data are not publicly available due to privacy or ethical restrictions.

\section{Introduction: Integrating Cultural and Natural Heritage in Urban Landscapes}

"The preservation of the built heritage alone is not sufficient to create a distinctive urban form or to sustain a city's spatial spirit” (Khirfan, 2010, p. 316)

Over the past few decades, there have been numerous studies examining the interface between cultural heritage conservation and urban (re)development, particularly in rapidly urbanising regions (Bandarin \& van Oers, 2012; Barber, 2013; Cartier, 1998; Jenkins \& King, 2003; Logan, 2002). In such studies, cultural heritage primarily pertains to the built (tangible) and lived (intangible) characteristics of place that are considered to be of historic or symbolic value to a particular society. On the other hand, scholars have also examined nature conservation movements in the context of encroaching (urban) development, which have primarily sought to conserve the biophysical characteristics of place such as coastlines, topographic landmarks, flora and fauna (Bengston \& Youn, 2006; Jim, 2005; Lorimer, 2008; Neo, 2007). However, this body of research has, with a few exceptions (e.g. Daly and Winter, 2012; Ishizawa, 2014; 2017), not considered the importance of the interplay of both natural and cultural heritage in urban settings, and the myriad connections between the two.

This article is protected by copyright. All rights reserved. 
This divide can be seen in the way in which heritage is currently managed both at local and international scales. Even as place and urban identities are often forged by the coalescence of both their cultural as well as natural constituents (Daniels, 1994; Nesbitt \& Weiner, 2001); it is clear that considerations over the development and management of one have often been at the expense of the other, without much attempt towards integration (see Daly and Winter, 2012). As Head and Muir (2006, p. 506) have noted, "natural and cultural heritage are frequently managed by different agencies, or different parts of a single agency, although they may be part of the same landscape". This 'division' within the concept of heritage is also captured in UNESCO's categorisation of World Heritage Sites into 'natural' and 'cultural' heritage sites. ${ }^{i}$ However, the rapid spatial expansion of many cities around the world is erasing the traditional dichotomies of city versus countryside and of cultural versus natural, as has been well documented by the literature in geography and, specifically, urban political ecology (UPE) (Cronon, 1991; Hinchliffe \& Whatmore, 2006; Kaika, 2005; Swyngedouw, 2006). ${ }^{\text {ii }}$

This culture-nature divide is especially apparent on the island-city of Penang, Malaysia, where tangible cultural heritage in the historic center of Georgetown has taken priority over other forms of heritage elsewhere on the island (Speechley, 2014). While there is pressure on all forms of heritage in Penang, the city's hills are increasingly under development pressure, as they do not have the same protection as the historic town center. ${ }^{\text {iii }}$ Therefore, local NGOs have become more vocal about the need to limit the encroachment of urbanisation into the hillsides (Connolly, 2019a; Dermawan, 2016; 2017). In these movements, invocations of Penang's rich natural heritage are often framed alongside urban and cultural heritage in local resistance to ongoing development projects on the island. As the World Commission on Culture and Development has argued, "cultures cannot survive if the environment on which they depend is laid to waste or impoverished", stressing the interdependencies between these categories (cited in Bandarin \& van Oers, 2012, p. 84). In analysing the case of Penang, I assert 
that it is only by looking at both the natural and cultural components of the island that we begin to develop a holistic picture of the specific heritage landscape.

Conceptually, I draw on insights from the field of urban political ecology, which has been at the forefront of investigating the inter-relations between nature and culture in urban contexts (Gandy, 2013; Heynen et al., 2006; Swyngedouw, 2006). However, UPE has yet to examine the topic of heritage, which I contend is an area with much potential for the field. More specifically, I draw on conceptualisations of landscape within political ecology which are useful for breaking down entrenched binaries between the cultural and natural, urban and rural (see Connolly, 2019b; Neumann, 2011; Walker \& Fortmann, 2003). Through such a holistic understanding, I hope to highlight the potential of urban heritage research in contributing to sustainable development initiatives through the integration and conservation of cultural and natural components of heritage landscapes. ${ }^{\text {ivv }}$

Much of the material presented in section three of this paper is based on documentary analysis, in particular a book compiled by a number of local scientists, professionals and activists, titled Penang Hill: The Need to Save Our Natural Heritage (Khor et al., 1991). This allowed for understanding the discursive attachment of Penangites to the Hill, in addition to the history of development and conservation initiatives. This was supplemented by 22 key informant interviews with civil society activists, scholars, urban planners and local residents from January-June, 2017 to document more recent development plans and conservation initiatives for Penang Hill. ${ }^{\mathrm{vi}}$ In addition, I conducted narrative analysis of local newspaper articles on Penang Hill, planning documents, and personal observations. ${ }^{\text {iii }}$ Newspapers analysed included various English dailies in Malaysia, which provided information on development on Penang Hill that would otherwise not be obtainable through interviews. Together, these

This article is protected by copyright. All rights reserved. 
methods allowed for interrogating the ways in which the heritage of Penang Hill is constructed, understood, and challenged by various stakeholders.

Following a brief review of the pertinent literature in UPE and landscape research, the paper then turns to an overview of Penang, followed by a 'reading' of Penang Hill and its centrality to Penang's cultural and spatial identity. In doing so, the paper considers alternative visions for Penang Hill, and how future development might be done in a way that complements the cultural and ecological attributes of the hill and respects its carrying capacity. It concludes by considering the implications of this case for wider questions of the role of heritage conservation in urban sustainability and environmental management. As such, it aims to spark a new generation of research into the political ecologies of urban heritage, which can offer important political and conceptual insights into the role of heritage in controversies over urban (re)development.

\section{Towards a Landscape Political Ecology of Urban Heritage}

As various scholars have documented, the term 'heritage' is a malleable and relational concept that has different meanings to different people (Barber, 2013; Winter and Daly, 2012; Jenkins, 2008, p. 149). Gardner et al. (2011, p.2) define heritage as "the accumulated riches of the past which have been entrusted to us, so that we may pass them on intact to future generations". Yet, as mentioned above, discussions over the cultural and the natural, both in academia and in conservation practice, have tended to separate the two (see DeSilvey, 2017;

Winter and Daly, 2012). For instance, King's (2016) book on UNESCO World Heritage sites in Southeast Asia adheres to UNESCO's separation of cultural and natural sites. Not only does it fail to note that this is a problematic separation, but also divides the cultural sites even further into urban, monumental, and rural sites (see King, 2016, p. 16). The edited collection This article is protected by copyright. All rights reserved. 
Routledge Handbook of Heritage in Asia (Daly and Winter, 2012), does make an attempt to reconcile these two aspects of heritage, but no chapter does so in an urban setting.

Therefore, as David C. Harvey (2003) has previously written in this journal, there is a need for more sophisticated theorisations of heritage both in theory and practice, which can help to identify the culture of urban natures, and vice versa (see Wilson, 1991). This is an important task for urban political ecologists specifically, given the important role of discourse, development, nature and culture in shaping notions of heritage. Indeed, as Jim (2005, p. 285) has argued, inadequate understanding of "natural-cum-cultural heritage" can hinder proper conservation movements. This underscores the need to connect these two aspects of heritage not only to improve heritage conservation outcomes, but more importantly, to foster more sustainable forms of urban development. Referring to Penang, Jenkins and King (2010, p. 48) have observed: "recently there has been an emergence of conservation awareness and the realisation among some local groups of the importance of their urban heritage for the general well-being of their environment". As the case presented in the following section indicates, the protection of cultural and natural heritage can be integrated with other societal concerns such as improving sustainability and socio-ecological well-being).

While there remains a dearth of work in geography and UPE which explicitly examines the relationship between cultural and natural heritage, geographers have been central to the task of illustrating the ways in which wilderness or nature is saturated with culture (Braun \& Castree, 1998; Cloke \& Jones, 2001; Jones \& Cloke, 2002; Head \& Muir, 2006). Urban political ecologists, similarly, have been central to demonstrating how cities are also profoundly natural spaces, adding empirical and conceptual substance to David Harvey's (1996, p. 186) now famous observation that "there is nothing unnatural about New York City" (emphasis in original). UPE has thus problematised earlier conceptions of the city as being purely social 
spaces devoid of nature (see Byrne and Wolch, 2010). This understanding was based on the separation of nature and culture into distinct ontological domains, originating in Greek philosophy and described by Latour $(1993 ; 2004)$ as 'the modern constitution' (see Byrne, 2011). The very essence of the two terms 'natural' and 'cultural', also makes it very difficult to speak or write about places in a non-dualistic manner. Hinchliffe $(2007$, p. 124) argued that this division is also partly a consequence of "the obsessions of social and cultural theory with cities, which reproduced the notion that there is nothing much of nature in the city". This conceptual divide also founded the basis of dominant conservation thinking, which sought to create natural spaces that were devoid of human interference (see Fairhead and Leach, 1996; Hecht, 2004).

UPE can thus provide a useful lens to examine controversies over urban heritage, by demonstrating how heritage landscapes "are produced through combined social and ecological processes that shape particular socio-geographical conditions and... transformations that shape everyday urban life (Swyngedouw, 2009, p. 603). Much writing in UPE draws on poststructural thinking to conceptualise both the agency of nature and the ways in which it is socially and discursively constructed (Braun, 2005; Gabriel, 2014). For instance, Swyngedouw (2006) has used the terms 'socio-nature' and 'cyborg urbanisation', drawing on writers like Bruno Latour and Donna Haraway. Furthermore, UPE adds a specific focus on political economy which helps to illustrate how culture-nature relations are shaped by capitalism, colonialism and conservation practices, amongst other factors, as will be demonstrated in the following sections.

Writing on the political ecology of landscape have also been useful to deconstructing such dualisms, as landscape is a holistic concept which captures the web of cultural, environmental and historical associations which are integral components in the formation of place attach-

This article is protected by copyright. All rights reserved. 
ment (Connolly, 2017; Neumann, 2011; Walker \& Fortmann, 2003). Landscape has thus been defined as "a way of seeing the world and imagining our relationship to nature" (Wilson, 1991, p. 14). Similarly, Caballero (2016, p. 8) has noted that: "landscapes are products of harmony between nature, history and culture of a specific area" (see also Ishizawa, 2017). This understanding draws on earlier writing on landscape in cultural geography, which has demonstrated how landscapes can influence environmental sensibilities of their inhabitants, and normative understandings of how the landscape should be used (Cosgrove \& Daniels, 1998; Duncan \& Duncan, 2001; Schein, 1997). However, Hinchliffe (2007, p. 208) has observed that some of this earlier writing suggests that the process of landscape formation has been treated as "the result of interactions between natural and cultural processes - both of which tended to be portrayed as somehow definable in and through the absence of the other". This indicates the value of the political ecology framing which can better conceptualise the hybrid, socio-natural character of landscapes.

Moreover, Connolly (2019b) has argued that a landscape political ecology (LPE) framework can provide powerful insights into the ways in which particular landscapes can be seen as crucial sites in generating local resistance to processes of urbanisation (see also Walker \& Fortmann, 2003, 469). For example, Barau (2016) identified landscape aesthetics, contact with nature, accessibility to green and open spaces/wilderness, and threats to wildlife to be some of the most important concerns to people and places experiencing possible landscape transformation in peri-urban settings (see also Byrne and Wolch, 2010. ${ }^{\text {viii }}$ As such, Bandarin \& van Oers (2012, p. 76) have attributed the growing awareness of the vulnerability of the urban environment as a key issue shaping approaches to heritage conservation in recent decades. Such work speaks to Kaika \& Swyngedouw's (2011) earlier call to investigate how place-specific physical environments can act as facilitators for collective action.

This article is protected by copyright. All rights reserved. 
Landscape is a particularly appropriate concept for understanding heritage as landscapes represent areas where "history, aesthetics and local place characteristics are conjoined in various comings-together as heritage" (Jones \& Cloke, 2002, p. 186). Landscape is thus a key concept used in international heritage legislation, such as the Burra Charter, which acknowledges the various associative values that contribute to the significance of place (Australia ICOMOS, 2013). Using a historic urban landscape (HUL) approach, Caballero (2016, p. 8) has since widened the dimensions of urban heritage to include all geological formations, flora and fauna, water bodies, agricultural lands and human settlements within and along the periphery of a designated area that contribute to the essence of a specific landscape. The significance of such an approach is that heritage management thus becomes a central component of the sustainable development of urban areas.

\section{The Urban Heritage of Penang Hill: Reworking Landscape, Culture and Nature}

George Town is the capital of the Malaysian state of Penang, in the northwestern part of peninsular Malaysia. It is a mid-sized city with approximately 700,000 people, located in the northeastern corner of Penang Island. The city is often referred to as Penang, as the metropolitan area extends across the entire island. The level of urbanisation in Penang is $90.8 \%$, which is among the highest in Malaysia, after Kuala Lumpur, Putrajaya and Selangor (Mok, 2016a). Penang's rapid and intensive urban transition has put considerable pressure on the natural environment, including its forested hills. It is largely this development pressure which has caused many Penangites to become increasingly alarmed by the loss of these valuable heritage assets, causing the impetus to push for enhanced protection of Penang's hills and associated flora and fauna (Dermawan, 2016; 2017; Looi, 2017). This speaks to the importance of community-led heritage movements, in which locals take seriously the value of their city's existing natural resources and heritage.

This article is protected by copyright. All rights reserved. 
Despite its name, Penang Hill (or Bukit Bendera) does not actually refer to a single hill, but rather an agglomeration of hills within the north-central part of Penang Island. These hills are connected by a ridge (with a paved road) which is the area commonly referred to as Penang Hill. The primary peaks encompassed in this area are Government Hill, Tiger Hill, Flagstaff Hill, and Western Hill, which is the highest peak on the island (830m). The Hill is famous for its swaths of primary tropical rainforest, the wide variety of flora and fauna found within them, the jungle trails and funicular tram leading up the hill, as well as its historic bungalows reflecting the island's colonial history (see Figure 1). Due to its accessibility and visibility from George Town, many Penangites have a strong cultural attachment to the hill, related to childhoods spent visiting its peaks, or merely the aesthetic charm that it offers (Chan, 2018; Khor et al., 1991). Penang Hill is thus understood by many Penangites to be central to the "unique atmosphere, heritage and cultural value" of Penang (Khor et al., 1991, p. 36), and a symbol of the island's identity (Gibby, 2017, p. 203).

<Figure 1 about here: A view from Penang Hill. Photo by author, 2017.>

In 1990, a Memorandum of Understanding (MoU) was signed by the Penang State Government, announcing their intention to develop Penang Hill into an 'international tourist resort', which caused unprecedented public controversy (Khor et al., 1991). The MoU was signed with the Berjaya Corporation - a Malaysian property developer specialising in leisure developments - based on a concept plan that they proposed. This plan would have not only affected Penang Hill itself, but also the Municipal Youth Park and the Botanic Gardens at its foothills. The Youth Park was to be developed into a 'water world complex', while a cablecar would be constructed to link Penang Hill with the Botanic Gardens (see Figure 2; Gibby, 2017). On the hill itself, the plan included an 'Acropolis' complex (consisting of a dome, planetarium, theatre, shopping and sports center); two large hotels; a condominium; forest 
lodge (with 300 units); and an 'Adventure Park' on Tiger Hill (consisting of a golf course, 'moon walk', 'space shuttle', 'haunted mansion' and 'shipwreck') (Khor et al, 1991). Following the MoU, the developer then had a year to come up with a detailed plan for their prospective developments, which would cover nearly the entire developable surface of the Hill (ibid). Given that Penang Island was completely forested upon the arrival of European settlers in 1786; two-thirds forested by 1900, and one-fifth forested in 1991, the Berjaya Plan was, as Mike Gibby (2017, p. 183) has remarked: "the next logical step towards deforesting the Hill completely". ix

\section{<Figure 2 about here. Caption: Map of Penang Hill and surrounding area. Base map}

\section{from openstreetmap.org.>}

Despite the proposed development plans on Penang Hill, it is specifically mentioned in the Structure Plan for Penang Island, which was approved by the (then) Municipal Council (Majlis Perbendaran Pulau Pinang - MPPP) in 1988. The section notes that "Penang Hill should be designated as an area of special characteristics. Its natural vegetation, topography and character as a hill resort must be maintained and conserved and any development shall conform to, and not destroy these special characteristics" (in Khor et al., 1991, p. 19). It goes on to note that the hill may be 'enhanced' by improving and increasing the various look-out points and the provision and maintenance of additional walkways, gardens and 'other facilities'. Moreover, a Local Plan for Penang Hill was gazetted in 1991, which seeks to promote the hill as a 'green, heritage destination' for 'nature and heritage tourism', while taking into account the carrying capacity of the site, and development constraints (Netto, 2013). However, the Local Plan and Structure Plan certainly do not allow for the type of large-scale development project envisioned by the Berjaya Plan for Penang Hill, described above.

This article is protected by copyright. All rights reserved. 
Such contradictions are also discernible amongst local residents, as one interviewee living near the base of Penang Hill, remarked: "Penang Hill is so beautiful, they should develop it like The Peak in Hong Kong, so that more people can enjoy it...but then, it will probably not be as beautiful anymore" (interview January 2017). While Penang civil society members and many residents are not against development, they maintain that any future development on the should be done in a sensitive manner which compliments the natural and cultural attributes of the hill, rather than the elaborate form of development envisioned by the Berjaya Plan (Gibby, 2017; Mok, 2016b). Indeed, as another resident observed much earlier, "just imagine how monstrous this beautiful hill will become with a 200-room luxury hotel, a 350-unit condominium... a shopping center...night clubs and discos [and so on]" (quoted in Khor, 1991, 42-3). Civil society members have pointed out that forested hills are Penang's natural heritage and function as water catchments to provide water supply, prevent soil erosion, flooding and landslides (Khor et al., 1991; Mizrah, 2013). They also host a rich diversity of plant and animal species, and act as 'green lungs' for CO2 buffering, nature appreciation and outdoor recreation activities (Penang Forum, 2016).

Various criticisms of the Berjaya Plan argued that it would "fundamentally alter the tranquil, natural atmosphere of the Hill, result in serious ecological impacts on the island and damage the hill's historic and heritage value" (Khor et al., 1991, 17). This led to the development of the 'Friends of Penang Hill' network, and a subsequent campaign to 'Save Penang Hill' - which was ultimately successful due to the unprecedented levels of public engagement and support that it attracted (nearly 30,000 signatures). The network consisted of various civil society groups and non-governmental organisations (NGOs), including: the Consumers' Association of Penang (CAP); Malayan Nature Society (MNS); Sahabat Alam (Friends of the Earth) Malaysia (SAM); Aliran and many others, including the Penang Heritage Trust (PHT) which pledged solidarity with the movement. The campaign was ultimately successful, and 
even resulted in the then Chief Minister of Penang Dr. Lim Chong Eu losing his seat in the 1990 general elections, which he had held for 21 years (ibid). This illustrates how unsavoury developments like the Berjaya Plan can serve as facilitators to collective action, and how forms of place-attachment can shape grassroots approaches to heritage conservation.

The historical significance of Penang Hill relates to its history as the first hill station built in Asia during the British colonial period, which is the origin of many of the heritage buildings remaining on the hill today (Aiken, 1987). Therefore, while Penang Hill is very much a 'natural' space, it is also one that was socially 'constructed' (see Wilson, 1991). As Aiken (1987, p. 439) notes, "Penang Hill was a sociocultural product of the dominant European colonial community in an alien and distant milieu". While Penang Hill invoked a sense of nostalgia for the distant homelands of the (British) civil servants, planters, military and other personnel who used the Hill in the colonial era; it similarly provides a sense of nostalgia for current residents of Penang for the rainforest landscapes that were abundant when Penang Island was less urbanised. 'Natural' landscapes like Penang Hill thus embody past and present social relations, which is a point that been made by a plethora of work in the literature on landscape in cultural geography (Cosgrove \& Daniels, 1988; Demeritt, 1994; Mitchell, 1996; 2008). ${ }^{\mathrm{x}}$

However, the colonial use of Penang Hill is not like other experiences with nature conservation whereby European ideas and institutions sought to create a landscape devoid of humans (see Fairhead and Leach, 1996; Hecht, 2004); but rather a "landscape of inhabitation”, based on the maintenance of inter-relations between humans and non-human landscapes, producing changes to both parties (Hinchliffe, 2002, p. 215; see also, Ishizawa, 2017). What Khor et al. (1991) find most significant about the built landscape of the Hill is the sensitive manner in which it was developed over the years. This refers not only to the limited number of bungalows and hotels on the Hill, but also the way in which these buildings 
were designed to blend in with the natural landscape as much as possible, and the absence of vehicular traffic (see Gibby, 2017).

This sensitive and slow-pace of development over the years has been recognised by locals as one of the major attractions of George Town as a whole - in that "it has not really changed over the decades. Much of the city is still discernible from old photographs and if the tourist wanted to see modern urban development, he could always go to Singapore instead" (Mason in Khor, 1991, p. 45). Yet, as has been documented by other scholars of Malaysia, this valorisation of slow-paced development is not shared by local politicians for whom 'development' and 'modernity' are integral to the Malaysian nation-building project (Bunnell, 2004; Goh, 2002; Lepawsky, 2009). Indeed, Penang's politicians have been labelled 'development obsessed' for their frequent references to Hong Kong and Singapore as models to follow and expensive infrastructure projects (Connolly, 2019c; Nambiar, 2018; Netto, 2018; $\mathrm{Ng}, 2016)$. This will also be seen in the following section, whereby the State Government has continued to promote large development projects on Penang Hill, despite seeking to promote its cultural and natural heritage attributes.

Another important feature of the Hill is related to the natural environment, especially the cooler temperature on the Hill, which "furnishes a cool refuge" from the "sweltering heatglazed plains" below (Khor in Khor et al. 1991, p. 37). As Margaret Khor put it, the 'raw' and 'bracing' air on Penang Hill also has a tranquil effect which restores the spirit, nerves and enables one to "resume the battle for existence in the city" during the week (ibid). The phenomenological qualities of the Hill are posited to be central to its charm, with the "rainbowcoloured birds and butterflies", foliage, as well as the 'rushing sounds' made by the little waterfalls and streams (ibid). These qualities are amplified by the "wonderful panorama" below, with the "pulsing blue waters" of the Straits of Penang, and the 'dark haze' of Kedah Peak" 
(Khor in Khor, 1991, p. 37). Such comments pertaining to the biophysical environment of Penang Hill are illustrative of the imagined relationship of Penangites to the natural environment, and account for much of the cultural significance of the Hill.

The various architectural, historical, cultural and biophysical qualities of the Hill correspond to many of the ten selection criteria, or 'outstanding universal values' (OUVs) used by UNESCO in evaluating and designating World Heritage Sites (UNESCO, 2005). For example, Criterion (ii) specifically refers to the "interchange of human values over a span of time within a cultural area of the world on developments in architecture, town-planning or landscape design" (UNESCO, 2017). Others include criterion (v): “an outstanding example of traditional human settlement... which is representative of...human interaction with the environment"; (vii): "areas of exceptional natural beauty and aesthetic importance"; and (x): "significant natural habitats for in-situ conservation of biological diversity" (UNESCO, 2005). Two of these OUVs (ii and v) correspond to the criteria for cultural sites, while two relate to those for natural sites (vii and $\mathrm{x}$ ).

Since 1992, UNESCO has recognised sites that exhibit "significant interactions between people and the natural environment" as cultural landscapes (ibid). However, Penang does not feature on this list of cultural landscapes, which is largely due to the strict definition of the existing World Heritage Site to the inner city area of George Town. This is a significant omission, as one resident put it, "the hill to me is not only a part of the land but more a part of my being...it is a place to commune with nature" (in Khor, 1991, 42). This quotation underscores the importance of developing more progressive forms of inhabitation of urban landscapes based on modes of 'multi-species flourishing' which Donna Haraway and other scholars have argued is central to building more socio-ecologically just societies (DeSilvey, 2017; Haraway, 2016; Hinchliffe, 2002; Houston, et al., 2018). Yet, development projects in Penang are often planned without "seemingly any regard for the local community or the 
ecology of the island" (in Khor, 1991, p. 43). As Ishizawa (2014, p. 34) has lamented, even in efforts of nature conservation, the strategies employed have often been premised on a "utilitarian vision of resources and nature, bringing human needs to the front while leaving other aspects of nature and ecosystems in second place". Therefore, Rodney Harrison (2013, p.9) has proposed that we need to understand "heritage as an emergent property of the dialogical relationships between human beings and a range of other human and non-human actors and their environments" (see also Hinchliffe, 2002). To this end, in order for Penang Hill to be sustainable in the long term, the community will have to work with and not against nature.

\section{Penang Hill's (Re)Development Trajectories: From nature reserve to Biosphere re-} serve?

Penang Hill is touted by the Penang State Government as a 'green, heritage destination', and the recommended tourism theme for the Hill as 'nature and heritage tourism' (Netto, 2013). Penang Hill is managed by Penang Hill Corporation (PHC), formed in 2009, which manages the UNESCO World Heritage Site, is a state-owned corporation, directed largely by politicians. While Gibby (2017, p. 201) suggested that this might be a "positive step" for the hill, I would argue that this seems not to be the case. While the PHC discursively taps into the natural and cultural heritage aspects of the Hill, this is largely superficial. This is seen partly in the vision statement of the PHC, which has changed from: "A hill with a heart that bonds us together with the environment" (quoted in Gibby, 2017, p. 202), to the much more corporate: "to be the hill resort of choice in Malaysia" (PHC, 2019). Moreover, the PHC's website claims that the organization was formed "with the primary objectives of managing the funicular train system and the development of Penang Hill” (ibid). The website also describes the PHC's success with attracting "more and more tourists" up to Penang Hill, while many NGOs have argued that the government should be limiting the number of tour- 
ists. Like much tourism-led development in George Town, this has led to the 'disneyfication' of the Hill, with various artificial, Instagram-friendly developments, like the 'Owl Museum' and 'Snow House' at the former Post Office (see Gibby, 2017, p. 192; Wilson, 1991; Zukin, 1991)..$^{\mathrm{xi}}$

Despite increased awareness of Penang Hill's socio-ecological value, Penang Hill is still frequently targeted by the State Government for large scale development projects. One example is a cable car that was proposed to connect Penang Hill with the adjacent Youth Park and Botanical Gardens as a way of improving the efficiency of transport on the island. This was incorporated into the Bukit Bendera Draft Local Plan, produced by the State Government in 1993 and gazetted in 1997. While this plan was dismissed as 'unnecessary' in a 2001 World Wildlife Fund (WWF) report commissioned for the Prime Minister's Office, the plan again re-emerged in 2013 with an additional connection to the northwestern tip of Penang Island (WWF Malaysia, 2001) ${ }^{\text {xii }}$ The cable car was declared by the Malaysia Tourism and Culture Minister as, "not only a top priority in Penang but also for the country", and was included in the 11th Malaysia Plan (Hilmy, 2015).

While the cable car plan has been pursued to increase tourism revenues and improve transportation on the island, it has been consistently resisted due to its incompatibility with the Hill's natural environment, and limited carrying capacity. In response to these plans, Friends of Penang Hill representatives announced that they would embark on a 'Save Penang Hill 2.0' campaign if the State Government continued to push the project (Dermawan, 2017). They also asked for more public consultation in the planning procedures for the Hill, rather than simply announcing plans after contracts have been signed with developers (Netto, 2013; Tan, 2013). However, as one informant told me in an interview, the cable car plan is not likely to happen in the near future for the simple reason that the State Government cannot afford the RM325 million ( $£ 60$ mil.) that it would require.

This article is protected by copyright. All rights reserved. 
More recently, the PHC announced plans for two new hotels to be built on Penang Hill, claiming that these would "blend in well with the environment", and "be compatible with the history and heritage of Penang Hill" (Tan, 2018). This announcement, however, has been criticised by NGOs, pointing out that the largest hotel on Penang Hill has only 12 rooms, while one of the proposed hotels will contain 200 (Tan, 2018). As Thompson et al. (2017) caution, eco-tourism strategies can thus result in serious failings with regards to heritage conservation if the local governance regimes are ineffective. While there is strong legislation protecting the integrity of Penang's hills, this is largely not enforced by the government. This emphasises the need for the active role of local residents in co-directing the planning process and preserving important heritage landscapes (see Caballero, 2016).

Most alternative visions for Penang Hill are supportive of its use - in part - as a tourist resort, but argue that it should focus on natural tourism (Gibby, 2017; Khor et al., 1991). It is posited that the Hill and its flora and fauna could play an increasingly important role in recreation, nature tourism, conservation, scientific research and education, many of which are functions that it has always served. They used this line of reasoning to counter the State Government's emphasis on supporting increased numbers of visitors, by arguing that the Hill could cater to specialist groups of tourists who are willing to pay higher sums of money to experience the Hill's unique assets. Various stakeholders have noted that this would also be a more sustainable form of development, whereby "sustainable economic activities facilitate conservation efforts, and vice versa" while also requiring minimal capital investment (Chan, 2018; Khor et al., 1991; Gibby, 2017).

One example would be extending the Botanical Gardens at the base to encompass part of the Hill, which could educate visitors about the flowering hill shrubs and plants not found in lowland areas. Similarly, there has been no attempt to promote visits to the Hill after sun- 
set. As Gibby (2017) has pointed out, doing so would diversify the range of activities visitors to the Hill can experience, such as star-gazing, dining out, or gazing down at the lights of George Town and Butterworth, which are all 'traditional' Hill activities. Underlining these sentiments, one concerned Penangite wrote, "if tourists go up the hill, it is because of its fresh charm and relaxing atmosphere, not any man-made amenities...it has a natural loveliness that needs no touching up" (in Khor 1991, p. 41).

Responding to public pressure, the Penang State Government announced in October, 2016, that it would seek UNESCO Biosphere Reserve Listing for Penang Hill, which would grant the same level of protection as the George Town UNESCO site (Ngui, 2016; The Star, 2016). Biosphere Reserves are described by UNESCO (2017) as "learning sites for sustainable development", which "promote solutions reconciling the conservation of biodiversity with its sustainable use". Biosphere Reserve nominations must come from the Malaysian (Federal) Government, which requires active cooperation between the government, scientists, and other stakeholders. While the status is still pending (at time of writing), designation would promote and support biodiversity research to be conducted on the Hill, which will help to document and conserve the Hill's unique flora and fauna. UNESCO Biosphere listing would be consistent with the alternative visions for Penang Hill outlined above and could be done with minimal infrastructure. It would thus serve the goal of educating visitors about the Hill and its ecological, cultural and social importance to Penang Island (Chan, 2018). This is a point highlighted in the Penang Strategic Development Plan (2001), which emphasises the need for sustainable tourism, meaning that there should be "no degradation to those very attributes that make the place a viable tourist attraction in the first place" (quoted in Gibby 2017, p. 181).

This model of sustainable development has finally been accomplished in part by The Habitat at Penang Hill - which is a private sector, eco-tourism based attraction located near 
the Upper Station. The Habitat promotes exploration of the Hill's intrinsic identity, unique features and attributes. It has a wide walking path, canopy walkway and zip line, which allow visitors to experience the natural environment of the summit area. Most interviewees consulted agree that this is a positive development and a good sign for the future of the Hill. Indeed, the Habitat Foundation which manages the site is actively involved in conducting research necessary to support and justify Biosphere Reserve listing (Chan, 2018). As Head and Muir (2016) have noted, such forms of community action help to identify possibilities for transformative potential with regards to sustainable urban development.

However, the State Government in 2018 announced a plan for a RM9 billion ( $£ 1.66$ billion) highway, which would tunnel through 10km of Penang's hills, including a bridge over the Penang Hill Railway. As a former senior UNESCO advisor familiar with Penang has claimed, this would be "clearly incompatible" with the Biosphere designation, and "in fact, seemed purposely designed to undermine and scuttle this conservation initiative" (quoted in Netto, 2018). Therefore, while the State Government continues to actively pursue the Biosphere Reserve nomination, it seems that this is being done largely for the purposes of tourism and promoting Penang and Penang Hill internationally (see Chern, 2018; Chow, 2018). For instance, the general manager of PHC was quoted as saying that the Biosphere Reserve project would help to attract up to 13,000 people up to Penang Hill simultaneously, which is far beyond the 4,000 deemed feasible by the WWF Report on Penang Hill (described above) and the 10,000 stated in the Penang Hill Structure Plan. As such, PHC's promotion of Penang Hill as a 'green, heritage designation', and a place where visitors can "see the nature, feel the history" is largely a green-washing strategy intended to attract tourists (PHC 2018; see also Chan, 2018).

This article is protected by copyright. All rights reserved. 


\section{Conclusion}

The controversies over the development of Penang Hill documented above has shed light on the challenges - but also the potentials - at stake in the conservation of urban heritage. While heritage conservation in the past has been hampered by rigid binaries of cultural/natural, tangible/intangible and urban/rural, the case of Penang illustrates how such binaries might be overcome. This is seen in the way in which heritage NGOs and activists in Penang have become increasingly concerned with emerging threats to the natural environment, and how these are negatively impacting Penang's rich heritage assets, which are seen as central to

Penangites' sense of place and well-being. In conceptualising this relationship, insights from writing on the political ecology of landscape have been instrumental in this effort, through its recognition of the integration of cultural and natural values embedded in the landscape, and holistic view of the urban and rural. While the concept of landscape has influenced both the academic literature on heritage and conservation approaches, I argue that insights from urban political ecology are also vital to better grasp the nature-culture dialectic at play in many urban landscapes. Acknowledging this relationship is especially important in order to develop and maintain landscapes that foster progressive relations with the natural world, which cannot be done through nature parks alone (see DeSilvey, 2017; Wilson, 1991).

In this regard, the paper has also paved the way for what might be termed an urban political ecology of heritage. While the more rural strand of political ecology has examined nature and biodiversity conservation issues (see Vaccaro et al., 2012 for a review), UPE has not to date engaged with heritage issues. This constitutes a considerable lacunae given the often unequal power relationships and struggles over land and resources that are often embedded within heritage controversies. Nonetheless, in addition to its conceptual tools for deconstructing binaries, I argue that UPE also provides a critical framework through which to

This article is protected by copyright. All rights reserved. 
examine controversies over the conservation of urban heritage landscapes. As Wilson (1991, p. 16) has argued, constructing forms of urban heritage conservation that are able to connect cultural and natural aspects of the landscape "must begin with understanding the process of contemporary land development" and everyday experiences of it. Concepts and methods from UPE may also help to inform heritage practitioners in integrating cultural and natural conservation strategies in urban settings.

Finally, the paper has also pointed to the importance of bottom-up approaches in creating and conserving integrated cultural/natural heritage landscapes, which adds to the academic literature on (urban) heritage governance. As Bandarin \& van Oers (2012) have put it: "local communities integrate natural and cultural components of any given locale through their daily practices and behaviour...into a singular experience", which is often not fully appreciated by urban governments. While the (State Government-led) Penang Hill Corporation has sought to promote the natural and cultural heritage components of the Hill, it has done so in a largely commercial way, merely seeking to develop the hill and attract increasing numbers of tourists. Yet, as local NGOs have shown, such approaches are untenable for conserving the historical and heritage significance of the Hill. As Kaika \& Swyngedouw (2011, p. 101) have argued, there is hence a need to "move away from 'resistance' to a demand for transformation". A transformation of dominant approaches to heritage conservation and urban development - "which can produce more equitable socio-ecological conditions, and imagine possible alternative urban natures" (ibid). This will require new governance mechanisms (such as the UNESCO Biosphere project) that can move beyond human-cantered approaches to conservation and development planning.

This article is protected by copyright. All rights reserved. 


\section{REFERENCES}

Aiken, S. R. (1987). Early Penang Hill Station. Geographical Review, 77, 421-439.

https://doi.org/10.2307/214282.

Australia ICOMOS. (2013). The Burra Charter: The Australia ICOMOS Charter for Places of Cultural Significance. Retrieved from https://australia.icomos.org/wp-content/uploads/The-Burra-Charter-2013Adopted-31.10.2013.pdf.

Bandarin, F. \& van Oers, R. (2012). The historic urban landscape: managing heritage in an urban century. Chichester, UK: Wiley Blackwell.

Barau, A. S. (2017). Tension in the periphery: An analysis of spatial, public and corporate views on landscape change in Iskandar Malaysia. Landscape and Urban Planning, 165, 256-266. https://doi.org/10.1016/j.landurbplan.2016.04.007.

Barber, L. B. (2013). Making meaning of heritage landscapes: The politics of redevelopment in Halifax, Nova Scotia. The Canadian Geographer / Le Géographe Canadien, 57, 90-112. https://doi.org/10.1111/j.1541-0064.2012.00452.x.

Bengston, D. N. \& Youn, Y.-C. (2006). Urban Containment Policies and the Protection of Natural Areas: The Case of Seoul's Greenbelt. Ecology \& Society, 11, 3-18. https://doi.org/10.5751/ES-01504-110103.

Berger, A.A. (1997). Narratives in Popular Culture, Media and Everyday Life. Thousand Oaks, CA: Sage.

Braun, B. (2005). Environmental Issues: Writing a "more than human” urban geography. Progress in Human Geography, 29, 635-650. https://doi.org/10.1191/0309132505ph574pr.

Braun, B. \& Castree, N. (1998). Remaking reality: nature at the millenium. London; New York: Routledge.

Bunnell, T. (2004). Malaysia, Modernity and the Multimedia Super Corridor: A Critical Geography of Intelligent Landscapes. London; New York: RoutledgeCurzon.

Byrne, J. (2011). The Human Relationship with Nature: Rights of Animals and Plants in the Urban Context. In I. Douglas, D. Goode, M. Houck \& R. Wang. (Eds.), The Routledge Handbook of Urban Ecology, 6373. New York, NY: Routledge.

Byrne, J. \& Wolch, J. (2009). Urban habitats / nature. In R. Kitchin. \& N, Thrift. (Eds.), International Encyclopaedia of Human Geography, pp. 46-50. Oxford, UK: Elsevier.

Caballero, G. V. A. (2016). The role of natural resources in the historic urban landscape approach. Journal of Cultural Heritage Management and Sustainable Development, 6, 2-13. https://doi.org/10.1108/JCHMSD-11-2014-0037.

This article is protected by copyright. All rights reserved. 
Cartier, C. (1998). Megadevelopment in Malaysia: From Heritage Landscapes to “Leisurescapes” in Melaka's Tourism Sector. Singapore Journal of Tropical Geography, 19, 151-176. https://doi.org/10.1111/j.1467-9493.1998.tb00257.x.

Cloke, P. \& Jones, O. (2001). Dwelling, Place, and Landscape: An Orchard in Somerset. Environment and Planning A, 33, 649-666. https://doi.org/10.1068/a3383.

Connolly, C. (2017). Landscape political ecologies of urban 'swiftlet farming' in George Town, Malaysia. Cultural Geographies, 24, 421-439. https://doi.org/10.1177/1474474016684128.

Connolly, C. (2019a). From resilience to multi-species flourishing: (Re)imagining urban-environmental governance in Penang, Malaysia. Urban Studies. https://doi.org/10.1177/0042098018807573.

Connolly, C. (2019b). Urban Political Ecology Beyond Methodological Cityism. International Journal of Urban and Regional Research, 43, 63-85. https://doi.org/10.1111/1468-2427.12710.

Connolly, C. (2019c). Worlding cities through transportation infrastructure. Environment and Planning A: Economy and Space, 51, 617-645. https://doi.org/10.1177/0308518X18801020.

Cosgrove, D. E., \& Daniels, S. (1988). The Iconography of landscape: essays on the symbolic representation, design, and use of past environments. Cambridge, UK; New York: Cambridge University Press.

Cronon, W. (1991). Nature's metropolis: Chicago and the Great West. New York, NY: W.W. Norton.

Daly, P. \& Winter, T. (2012). Routledge Handbook of Heritage in Asia. New York, NY: Routledge.

Daniels, S. (1994). Fields of vision: landscape imagery and national identity in England and the United States. Cambridge, UK: Polity Press.

Demeritt, D. (1994). The Nature of Metaphors in Cultural Geography and Environmental History. Progress in Human Geography, 18, 163-185. https://doi.org/10.1177/030913259401800203.

Dermawan, A. (2016). Group launches Penang Hills Watch site to monitor hill clearing activities, New Straits Times 31 October. Retrieved from: http://www.nst.com.my/node/184600.

Dermawan, A. (2017). People will “Save Penang Hill, again”, New Straits Times 4 February 2017. Retrieved from http://www.nst.com.my/news/2017/02/209515/people-will-save-penang-hill-again.

DeSilvey, C. (2017). Curated Decay: Heritage Beyond Saving. Minneapolis, MN: University of Minnesota Press.

Duncan, J. S. \& Duncan, N. G. (2001). The Aestheticization of the Politics of Landscape Preservation. Annals of the Association of American Geographers, 91, 387-409. https://doi.org/10.1111/0004-5608.00250.

This article is protected by copyright. All rights reserved. 
Fairhead, J. \& Leach, M. (1996). Misreading the African Landscape. Cambridge, UK: Cambridge University Press.

Gabriel, N. (2014). Urban Political Ecology: Environmental Imaginary, Governance, and the Non-Human. Geography Compass, 8, 38-48. https://doi.org/10.1111/gec3.12110.

Gandy, M. (2013). Marginalia: Aesthetics, Ecology and Urban Wastelands. Annals of the Association of American Geographers, 103, 1301-1316. https://doi.org/10.1080/00045608.2013.832105.

Gardner, S., Sitthisunthọ̄n, P. \& Lai, E. M. (2011). Heritage trees of Penang. Penang, Malaysia: Areca Books.

Gibby, M. (2017). Penang Hill - A Journey Through Time. Penang, Malaysia: Entrepot Publishing.

Goh, B.-L. (2002). Modern dreams: an inquiry into power, cultural production, and the cityscape in contemporary urban Penang, Malaysia. Ithaca, N.Y: Southeast Asia Program Publications, Cornell University Press.

Haraway, D. J. (2016). Staying with the trouble: making kin in the Chthulucene. Durham, NC: Duke University Press.

Harrison, R. (2013). Heritage: critical approaches. New York, NY: Routledge.

Harvey, D. (1996). Justice, nature and the geography of difference. Cambridge, UK: Blackwell.

Harvey, D. C. (2003). "National" identities and the politics of ancient heritage: continuity and change at ancient monuments in Britain and Ireland, c.1675-1850. Transactions of the Institute of British Geographers, 28, 473-487. https://doi.org/10.1111/j.0020-2754.2003.00105.x.

Head, L., \& Muir, P. (2006). Suburban life and the boundaries of nature: resilience and rupture in Australian backyard gardens. Transactions of the Institute of British Geographers, 31, 505-524. https://doi.org/10.1111/j.1475-5661.2006.00228.x.

Hecht, S. (2004). Invisible forests: the political ecology of forest resurgence in El Salvador. In R. Peet \& M. Watts (Eds.), Liberation ecologies: environment, development, social movements, 2nd ed, 58-93. London, UK: Routledge.

Heynen, N., Kaika, M. \& Swyngedouw, E. (2006). Urban political ecology: Politicizing the production of urban natures. In N. Heynen, M. Kaika, \& Swyngedouw, E. (Eds.), In the Nature of Cities: Urban Political Ecology and the Politics of Urban Metabolism, 1-21. London, UK: Routledge.

Hilmy, I. (2015). Proposed cable car project will benefit Penang, The Sun Daily 2 May 2015. Retrieved from http://www.thesundaily.my/news/1405592.

This article is protected by copyright. All rights reserved. 
Hinchliffe, S. (2002). 'Inhabiting' - Landscapes and Natures. In K. Anderson, M. Domosh, S. Pile, \& Thrift, N. (Eds.), Handbook of cultural geography, 207-225. Thousand Oaks, CA: Sage.

Hinchliffe, S. (2007). Geographies of nature: societies, environments, ecologies. Los Angeles, CA: Sage Publications.

Hinchliffe, S. \& Whatmore, S. (2006). Living Cities: Towards a Politics of Conviviality. Science as Culture, 15, 123-138. https://doi.org/10.1080/09505430600707988.

Houston, D., Hillier, J., MacCallum, D., Steele, W. \& Byrne, J. (2018). Make kin, not cities! Multispecies entanglements and 'becoming-world' in planning theory. Planning Theory, 17, 190-212. https://doi.org/10.1177/1473095216688042.

International Council on Monuments and Sites (ICOMOS). (2016). ICOMOS \& IUCN Partner on NatureCulture Journey at the World Conservation Congress 2016, International Council on Monuments and Sites). Retrieved from http://www.icomos.org/en/178-english-categories/news/5760-icomos-iucnpartner-on-nature-culture-journey-at-the-world-conservation-congress-2016.

Ishizawa, M. (2014). About the Conservation of Cultural Landscapes: Sustainability or Unviability? Unpublished PhD Thesis. Brandemburg University of Technology, Cottbus.

Ishizawa, M. (2017). Landscape change in the terraces of Ollantaytambo, Peru: an emergent mountain landscape between the urban, rural and protected area. Landscape Research, 42, 321-333. https://doi.org/10.1080/01426397.2016.1267132.

Jenkins, G. (2008). Contested Space: Cultural Heritage and Identity Reconstructions Conservation Strategies within a Developing Asian City. Zurich, Switzerland: Lit Verlag.

Jenkins, G. \& King, V. T. (2003). Heritage and development in a Malaysian city: George Town under threat? Indonesia and the Malay World, 31, 44-57. https://doi.org/10.1080/13639810304441.

Jim, C. Y. (2005). Monitoring the performance and decline of heritage trees in urban Hong Kong. Journal of Environmental Management, 74, 161-172. https://doi.org/10.1016/j.jenvman.2004.08.014.

Jones, O. \& Cloke, P. J. (2002). Tree cultures: the place of trees and trees in their place. Oxford ; New York: Berg.

Kaika, M. (2005). City of Flows: Modernity, Nature and the City. London, UK: Routledge.

Kaika, M. \& Swyngedouw, E. (2011). The Urbanization of Nature: Great Promises, Impasse, and New Beginnings. In G. Bridge \& S. Watson (Eds.), The New Blackwell Companion to the City, 106-117. Malden, MA: Blackwell.

This article is protected by copyright. All rights reserved. 
Khirfan, L. (2010). Traces on the palimpsest: Heritage and the urban forms of Athens and Alexandria. Cities, 27, 315-325. https://doi.org/10.1016/j.cities.2010.03.009.

Khor, M. \& Friends of Penang Hill. (Eds.). (1991). Penang Hill: the need to save our natural heritage: critique of the proposed development and alternative plan. Penang, Malaysia: Friends of Penang Hill.

King, V. T. (Ed.). (2016). World Heritage in Southeast Asia: Issues, Prospects and Problems. In UNESCO in Southeast Asia: World Heritage sites in comparative perspective (pp. 1-30). Copenhagen, Denmark: NIAS Press.

Latour, B. (1993). We have never been modern. Cambridge, MA: Harvard University Press.

Latour, B. (2004). Politics of nature : how to bring the sciences into democracy. Cambridge, MA: Harvard University Press.

Lepawsky, J. (2009). Clustering as Anti-Politics Machine? Situating the Politics of Regional Economic Development and Malaysia’s Multimedia Super Corridor. Regional Studies, 43, 463-478. https://doi.org/10.1080/00343400802331338.

Logan, W. (2012). The disappearing "Asian" city: protecting Asia's urban heritage in a globalizing world. Oxford, UK: Oxford University Press.

Looi, S.-C. (2017). We'll kick you out, groups warn Penang govt over hillside development, The Malaysian Insight 23 October 2017. Retrieved from https://www.themalaysianinsight.com/s/19639/.

Lorimer, J. (2008). Living roofs and brownfield wildlife: towards a fluid biogeography of UK nature conservation. Environment and Planning A, 40, 2042-2060. https://doi.org/10.1068/a39261.

Mitchell, D. (1996). The lie of the land: migrant workers and the California landscape. Minneapolis, MN: University of Minnesota Press.

Mitchell, D. (2008). New Axioms for reading the Landscape: Paying Attention to Political Economy and Social Justice. In J. L. Wescoat \& D. M. Johnston (Eds.), Political economies of landscape change places of integrative power (pp. 29-50). New York, NY: Springer.

Mizrah, R. (2013). Rexy's thoughts: Penang Hill Special Area Plan (SAP), RexyMizrah 11 December 2013. Retrieved from https://rexymizrah.wordpress.com/tag/teluk-bahang/.

Mok, O. (2016a). Massive projects in place to alleviate urbanisation in Penang, The Malay Mail 26 October 2016. Retrieved from http://www.themalaymailonline.com/malaysia/article/massive-projects-in-placeto-alleviate-urbanisation-in-penang.

This article is protected by copyright. All rights reserved. 
Mok, O. (2016b). State Opposition leader questions planned development for Penang Hill, 17 November 2016.

Retrieved from http://www.themalaymailonline.com/malaysia/article/state-opposition-leaderquestions-planned-development-for-penang-hill.

Nambiar, P. (2018). Chow: If HK Had to take advice of Penang NGOs, it would still be backward, FMT News 16 November 2018. Retrieved from https://www.freemalaysiatoday.com/category/nation/2018/11/16/chow-if-hk-had-to-take-advice-ofpenang-ngos-it-will-still-be-backward/.

Nesbitt, J. T. \& Weiner, D. (2001). Conflicting environmental imaginaries and the politics of nature in Central Appalachia. Geoforum, 32, 333-349. https://doi.org/10.1016/S0016-7185(00)00047-6.

Neo, H. (2007). Challenging the developmental state: Nature conservation in Singapore. Asia Pacific Viewpoint, 48, 186-199. https://doi.org/10.1111/j.1467-8373.2007.00340.x.

Neumann, R. P. (2011). Political ecology III: Theorizing landscape. Progress in Human Geography, 35, 843850. https://doi.org/10.1177/0309132510390870.

Ngui, A. (2016). Efforts to get Penang Hill listed as a Unesco Biosphere Reserve, The Sun Daily 5 October 2016. Retrieved from http://www.thesundaily.my/news/1992843.

Penang Forum. (2016). Penang Forum launches Penang Hills Watch online crowd-sourcing, mapping initiative, Penang Forum 31 October. Retrieved from https://penangforum.net/2016/10/31/penang-forumlaunches-penang-hills-watch-online-crowd-sourcing-mapping-initiative/.

Penang Hill Corporation (PHC). (2019). About Us. Retrieved from http://penanghill.gov.my/index.php/en/about-us.html.

Schein, R. (1997). The place of landscape: a conceptual framework for interpreting an American scene. Annals of the Association of American Geographers, 87, 660-680. https://doi.org/10.1111/1467-8306.00072.

Speechley, S.-T. (2014). Penang's Heritage Wealth Goes Way Beyond the UNESCO Site. Penang Monthly. January. Retrieved from http://penangmonthly.com/penangs-heritage-wealth-goes-way-beyond-theunesco-site/.

The Star. (2016). Biosphere Reserve pitch for Penang Hill, The Star 6 October 2016. Retrieved from https://www.thestar.com.my/news/nation/2016/10/06/biosphere-reserve-pitch-for-penang-hill/.

Swyngedouw, E. (2006). Circulations and metabolisms: (Hybrid) Natures and (Cyborg) Cities. Science as Culture, 15, 105-121. https://doi.org/10.1080/09505430600707970.

This article is protected by copyright. All rights reserved. 
Swyngedouw, E. (2009). The Antinomies of the Postpolitical City: In Search of a Democratic Politics of Environmental Production. International Journal of Urban and Regional Research, 33, 601-620. https://doi.org/10.1111/j.1468-2427.2009.00859.x.

Tan, S. C. (2018). Penang Hill Projects to go ahead. The Star Online, 21 November 2018. Retrieved from https://www.thestar.com.my/news/nation/2018/11/21/penang-hill-hotel-projects-to-go-ahead-phc-twolodging-facilities-to-be-built-on-dilapidated-buildin/.

Tan, S. H. (2013). So where is the Penang Local Plan? - Letters, The Star Online 7 October. Retrieved from http://www.thestar.com.my/opinion/letters/2013/10/07/so-where-is-the-penang-local-plan/.

Thompson, B. S., Gillen, J. \& Friess, D. A. (2018). Challenging the principles of ecotourism: insights from entrepreneurs on environmental and economic sustainability in Langkawi, Malaysia. Journal of Sustainable Tourism, 26, 257-276. https://doi.org/10.1080/09669582.2017.1343338.

UNESCO, W. H. C. (2005). The Criteria for Selection. Retrieved from http://whc.unesco.org/en/criteria/.

UNESCO, W. H. C. (2017). Biosphere Reserves. Retrieved from http://www.unesco.org/new/en/naturalsciences/environment/ecological-sciences/biosphere-reserves/.

Vaccaro, I., Beltran, O., \& Paquet, P. A. (2013). Political ecology and conservation policies: some theoretical genealogies. Journal of Political Ecology, 20, 255. https://doi.org/10.2458/v20i1.21748.

Walker, P., \& Fortmann, L. (2003). Whose Landscape? A political ecology of the "exurban” Sierra. Cultural Geographies, 10, 469-491. https://doi.org/10.1191/1474474003eu285oa.

Wilson, A. (1991). The culture of nature North American landscape from Disney to the Exxon Valdez. Toronto, Canada: Between the Lines.

Winter T. \& Daly P. (2012). Heritage in Asia: Converging forces, conflicting values. In P. Daly \& T. Winter (Eds.) Routledge handbook of heritage in Asia. New York, NY: Routledge.

WWF Malaysia. (2001). Study on the Development of Hill Stations (pp. 1-168). Economic Planning Unit, Prime Minister's Department. Retrieved from http://www.repository.wwf.org.my/technical_reports/W/WWFM_Hill\%20Stations\%20Study\%20Vol2 _2001.pdf.

Zukin, S. (1991). Landscapes of power: from Detroit to Disney World. Berkeley, CA: University of California Press.

This article is protected by copyright. All rights reserved. 


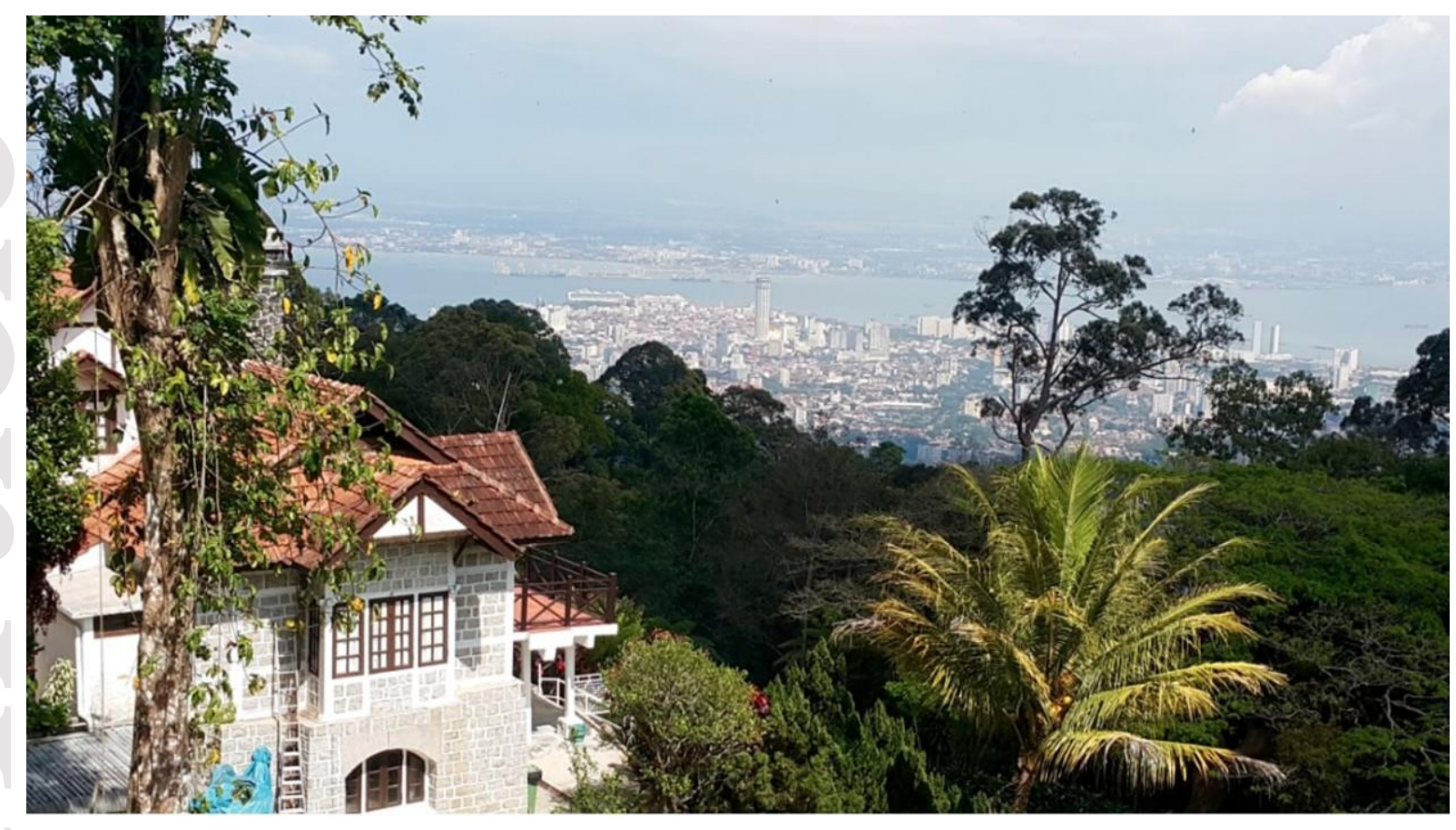

A view from Penang Hill. Photo by author, 2017

This article is protected by copyright. All rights reserved. 


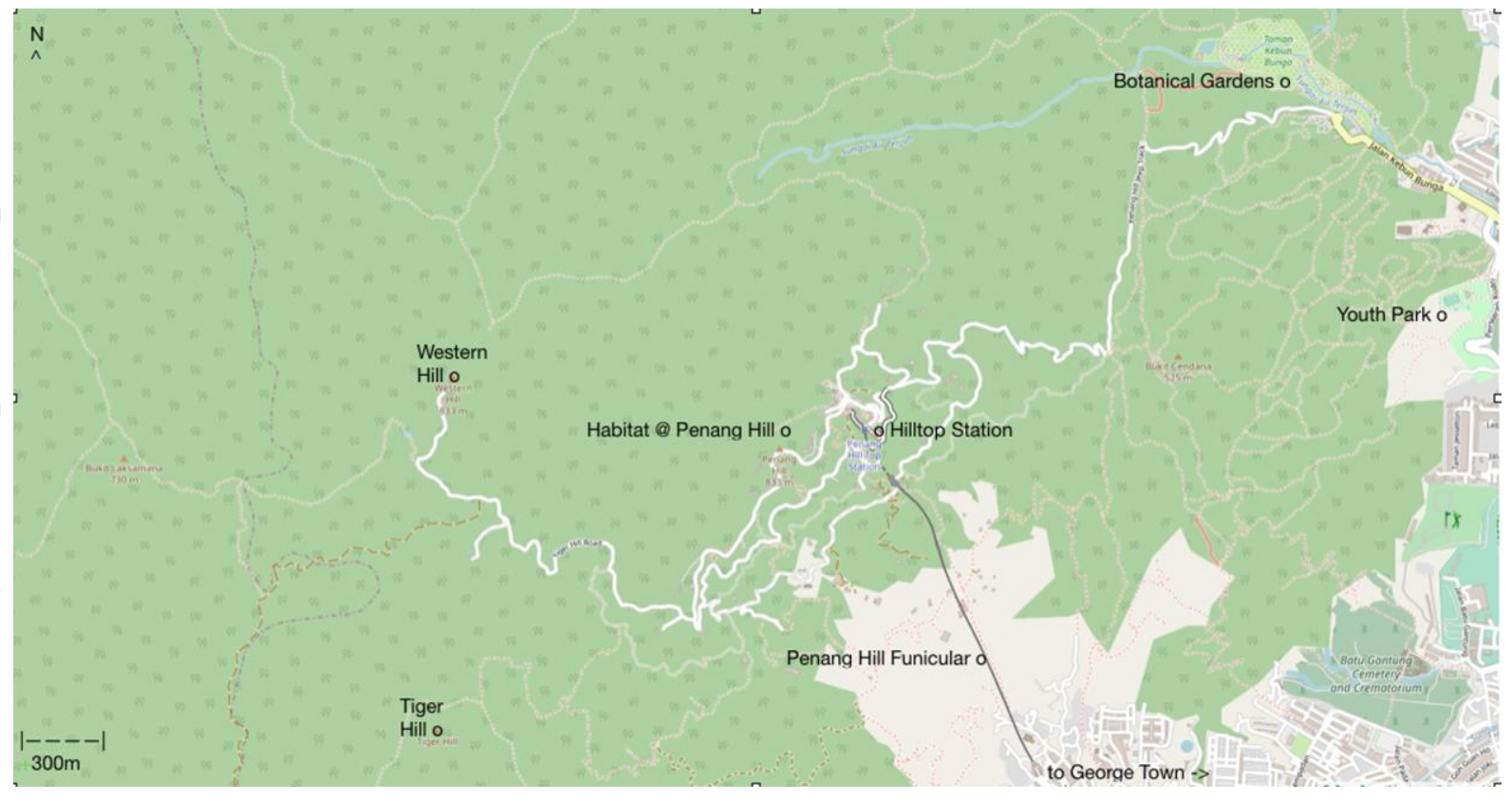

Map of Penang Hill and surrounding area. Base map from openstreetmap.org.

This article is protected by copyright. All rights reserved. 


\section{ENDNOTES}

\footnotetext{
i There is also a smaller 'mixed' category, but, as of February 2017, this only constitutes 35 out of 1052 total sites.

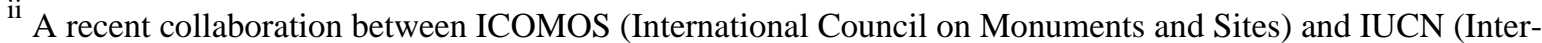
national Union for the Conservation of Nature) has sought to address this gap through a joint 'culture-nature journey' to better recognise the relationship between cultural and natural components of heritage sites worldwide (ICOMOS, 2016).

${ }^{\text {iii }}$ For a detailed critique of the UNESCO approach to heritage conservation, see Ishizawa (2014).

iv While various terms have been proposed to indicate the interconnection between cultural and natural landscapes, such as 'natural-cum-cultural' heritage (Jim 2005) and 'historic urban landscape (Caballero, 2016), I use the notion of urban heritage to incorporate both of these dimensions.

${ }^{v}$ By sustainable development, I refer to development which does not negatively impact the nature of biodiversity, and traditional cultural practices (handed down from previous generations) (see Winter and Daly, 2012).

${ }^{\mathrm{vi}}$ These interviews were conducted as part of a larger project seeking to understand urban redevelopment, heritage conservation and urban governance initiatives in Penang, and were not all relevant to this particular paper.

Ethical clearance was granted by the Institutional Review Board, National University of Singapore, for the period Dec. 2016 - Dec. 2018.

vii Narrative analysis was done manually, using an inductive coding approach with the following thematic groupings informed by the conceptual framing of my research: cultural/natural heritage, landscape, aesthetics, nature-society relationships, ecosystems services and sustainable development (see Berger, 1997).

${ }^{\text {viii }}$ Duncan \& Duncan (2001, p. 391) define aesthetics as "the unarticulated, unmediated and naturalised pleasure one takes in the concrete materiality of things in themselves".

ix Today, only seven percent of Penang State's forests remain in tact.

${ }^{\mathrm{x}}$ While I am aware of the argument that the beauty of landscapes like Penang Hill "can obscure the exclusion as well as the exploitation that produces them" (Duncan \& Duncan 2001: 389), this is a point that is beyond the scope of the present paper, and has been documented elsewhere (see Aiken, 1987; Gibby, 2017)

${ }^{x i}$ Disneyfication refers to "the transformation of a location to resemble one of Walt Disney's theme parks - becoming totally artificial, but 'pretty' and entertaining. It is the stripping of a place...of its original character and repackaging it” (Gibby, 2017: 192; see also Wilson, 1991; Zukin, 1991).

xii 'Study on the Development of Hill Stations Final Report', prepared for the Economic Planning Unit, Prime Minister's Department.
}

This article is protected by copyright. All rights reserved. 